The University of Maine

\title{
DigitalCommons@UMaine
}

Marine Sciences Faculty Scholarship

School of Marine Sciences

$1-1-2010$

\section{Descaling Injury Impairs the Osmoregulatory Ability of Atlantic Salmon Smolts Entering Seawater}

J.Zydlewski

Gayle Zydlewski

University of Maine - Main, gayle.zydlewski@umit.maine.edu

G. R. Danner

Follow this and additional works at: https://digitalcommons.library.umaine.edu/sms_facpub

\section{Repository Citation}

Zydlewski, J.; Zydlewski, Gayle; and Danner, G. R., "Descaling Injury Impairs the Osmoregulatory Ability of Atlantic Salmon Smolts Entering Seawater" (2010). Marine Sciences Faculty Scholarship. 32.

https://digitalcommons.library.umaine.edu/sms_facpub/32 


\title{
Descaling Injury Impairs the Osmoregulatory Ability of Atlantic Salmon Smolts Entering Seawater
}

\author{
JOSEPH ZYDLEWSKI* \\ U.S. Geological Survey, Maine Cooperative Fish and Wildlife Research Unit, University of Maine, \\ 5755 Nutting Hall, Orono, Maine 04469-5755, USA \\ GAYLE ZYDLEWSKI \\ School of Marine Sciences, University of Maine, Orono, Maine 04469-5706, USA \\ G. RuSSELl DANNER \\ Maine Department of Inland Fisheries and Wildlife, Augusta, Maine 04330, USA, \\ and Department of Biology, Colby College, Waterville, Maine 04901-8857, USA
}

\begin{abstract}
The effect of descaling injury on the osmoregulatory ability of hatchery Atlantic salmon Salmo salar smolts in seawater was investigated. Experimental series were initiated during early, middle, and late periods of the spring smolt migration (April 25, May 11, and May 31, respectively). For each time series, descaled smolts (subjected to descaling on $10 \%$ of the body surface area) and control smolts (held out of water for $15 \mathrm{~s}$ ) were transferred to seawater at $0,1,3$, or $7 \mathrm{~d}$ posttreatment. After fish were held in 35\%o seawater for $24 \mathrm{~h}$, gill and blood samples were collected and analyzed for $\mathrm{Na}^{+}, \mathrm{K}^{+}$-ATPase activity and plasma osmolyte levels. Based on gill $\mathrm{Na}^{+}, \mathrm{K}^{+}$-ATPase activity, the three series spanned the period from early smolting (increasing activity) to de-smolting (decreasing activity). In each series, descaled fish transferred to seawater at 0 and $1 \mathrm{~d}$ posttreatment had greater plasma osmolality than control fish; descaled fish transferred to seawater at $3 \mathrm{~d}$ posttreatment did not differ from controls. The greatest perturbation in osmolality (70 milliosmoles) was observed at the peak of smolting (middle series), whereas lesser increases were seen for early and late-series smolts. The observed osmotic perturbations in descaled fish would probably reduce performance and decrease survival during smolt migration.
\end{abstract}

Anadromous salmonid juveniles face both physical and physiological challenges during emigration. As smolts leave rearing habitats and migrate seaward, they encounter geomorphic barriers, changing flow, varying turbidity, and a gauntlet of predators. Upon reaching the sea, they encounter increased salinity, necessitating effective hypo-osmoregulation. The migratory success of smolts therefore depends upon behavioral strategies, swimming performance, and intact physiological abilities.

Prior to and during this period of migration,

\footnotetext{
* Corresponding author: jzydlewski@usgs.gov
}

Received March 18, 2009; accepted July 31, 2009

Published online November 5, 2009 salmonids undergo a suite of developmental shifts in morphology, physiology, and behavior considered to be adaptive for migration and marine life (McCormick and Saunders 1987; Hoar 1988). Smoltification is stimulated by increases in day length that occur in combination with warming spring temperatures (Hoar 1988; Muir et al. 1994), defining a smolt "window" for migration (McCormick et al. 1998). The ability of smolts to tolerate full-strength salinity is increased through a proliferation of mitochondrion-rich cells in their gills (Richman et al. 1987; McCormick 1993). This and other smolt characteristics develop in advance of seaward migration and regress if fish remain in freshwater (de-smoltification; McCormick et al. 1999; Handeland et al. 2001; Zydlewski et al. 2005).

The integument is an important component maintaining a smolt's homeostasis because it provides a physical barrier against passive diffusion. Injury to the integument impacts the permeability of this organ (Holeton et al. 1982; Kuperman et al. 2001) and therefore can directly impair osmoregulation. The effect of an injury with respect to osmoregulation may change during the parr-smolt transformation. While seawater tolerance is increased at the peak of the parr-smolt transformation, a heightened sensitivity to stressors is also evident (Carey and McCormick 1998). The hypo-osmoregulatory challenge of seawater entry may impair an injured smolt's ability to osmoregulate through the stress response.

Injuries to the integument result from natural and anthropogenic sources. On the Penobscot River, Maine, descaling is a commonly observed injury in migrating smolts of Atlantic salmon Salmo salar, particularly towards the end of the migratory season (FERC 1989; USASAC 2006). In hatcheries, repeated handling, transportation at high densities, and stocking can result in injuries (Bouck and Smith 1979). Although descaling is routinely used as an index of 


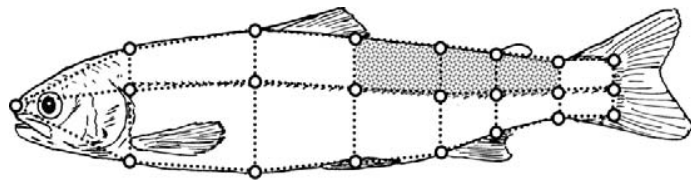

FIGURE 1.-Schematic of an Atlantic salmon smolt and the landmarks used to estimate surface area. Shaded area represents the area descaled as a standardized injury in this study.

physical damage, few studies have examined the physiological responses of salmonids to scale loss or with respect to subsequent performance and survival. The objectives of this study were to (1) evaluate the ability of Atlantic salmon smolts to successfully osmoregulate in seawater after receiving uniform descaling injuries; (2) characterize variations in the osmoregulatory response to descaling over the period of smolting; and (3) characterize the time course of physiological recovery from descaling.

\section{Methods}

Experimental fish.-Progeny of sea-run Penobscot River Atlantic salmon were reared under natural light in lake water at the Green Lake National Fish Hatchery (U.S. Fish and Wildlife Service) as part of the ongoing 1-year smolt stocking program utilizing sea-run adults (of both hatchery and wild origin). Peak migration (based on 50\% cumulative capture of stocked smolts) in the Penobscot River occurs between May 5 and May 16 (2001-2004; Ed Hastings, National Oceanic and Atmospheric Administration [NOAA] Fisheries, unpublished data). On April 11, 2005, 400 smolts were crowded, netted, and transferred by bucket from 9-m circular rearing ponds into two 1,000-L, flow-through $(10 \mathrm{~L} / \mathrm{min})$ tanks. Water temperature in the tanks increased from $4^{\circ} \mathrm{C}$ on April 11 to $17^{\circ} \mathrm{C}$ by June 6 . Simulated natural photoperiod was provided with 50 $\mathrm{W}$, wide-spectrum incandescent bulbs. Fish were fed daily to satiation (1.5-mm Hi-Pro Mini; Corey Feed Mills, Ltd., Fredericton, New Brunswick, Canada).

Estimating descaled surface area.-Efforts were made to select an area for uniform descaling that would represent approximately $10 \%$ of the body surface area ( $20 \%$ of one side). To estimate the descaled area needed, circumference measurements (using thread) for 19 fish (17.2-20.3 cm fork length [FL]) were taken at six positions along the flank of the fish (Figure 1). The position of the lateral line for each circumference was also measured with respect to the dorsal and ventral midlines. These measurements defined 14 polygons for each side that could be summed to estimate total surface area of the fish. Fish surface area was predicted using the linear regression equation $\left(R^{2}=0.86, P<0.001\right)$ :

$$
\mathrm{SA}=(\mathrm{FL} \times 129)-125,
$$

where SA is surface area $\left(\mathrm{cm}^{2}\right)$ and FL is in centimeters. This estimation of surface area is approximately $25 \%$ greater than an estimation generated from a two-dimensional image. The integument above the lateral line and behind the dorsal fin on the left side of each fish was descaled (Figure 1), representing an estimated $9.3 \pm 0.7 \%$ (mean $\pm \mathrm{SD}$ ) of the total surface area of the fish. Estimated proportional area for this region was not correlated with FL and therefore represented an area unaffected by fish size $(P=0.86)$.

Experimental design of descaling and seawater challenges.-Sampling began on April 25, May 11, and May 31, 2005, to assess the effects of descaling early in smolt development (early series), at the peak of the parr-smolt transformation (middle series), and during de-smolting (late series), respectively. The work was conducted at the Green Lake National Fish Hatchery. For each series, 60 randomly selected fish from each holding tank were anesthetized with tricaine methanesulfonate (MS-222; $100 \mathrm{mg} / \mathrm{L} ; 2.3-\mathrm{mM} \mathrm{NaH}-$ $\mathrm{CO}_{3} ; \mathrm{pH} 7.0$ ) in source water and were assigned to either descaled or control treatments in an alternate fashion. A blunt laboratory spatula was used to descale the integument; control fish were held out of water for a comparable time (15 s). Fish were allowed to recover in a 1,000-L tank supplied with freshwater.

After $1 \mathrm{~h}$ of recovery, 15 control and 15 descaled fish were nonselectively netted and transferred isothermally to an aerated, 333-L tank with seawater at a salinity level of 35\% (0-d sample; Instant Ocean, Bethesda, Maryland). The remaining 90 fish were maintained in flow-through freshwater in the 1,000-L tank until they were similarly transferred to seawater in groups of 30 (15 control and 15 descaled fish) at 1, 3, and $7 \mathrm{~d}$ posttreatment. Water temperatures ranged from $7^{\circ} \mathrm{C}$ to $8^{\circ} \mathrm{C}$ for the early series (April 25-May 2), from $9^{\circ} \mathrm{C}$ to $12^{\circ} \mathrm{C}$ for the middle series (May 16-23), and from $12^{\circ} \mathrm{C}$ to $17^{\circ} \mathrm{C}$ for the late series (May 30-June 6). Food was withheld for the $24 \mathrm{~h}$ prior to the descaling treatment or seawater transfer; otherwise, fish were fed as described above.

For each group transferred, all 30 fish were terminally sampled after $24 \mathrm{~h}$ in seawater. Fish were euthanized with MS-222, after which FL and mass were immediately measured. A gill biopsy was taken from each fish to measure gill $\mathrm{Na}^{+}, \mathrm{K}^{+}$-ATPase (enzyme code 3.6.3.9; IUBMB 1992) activity. Four gill filaments were removed and immersed in $100 \mu \mathrm{L}$ of ice-cold sucrose-EDTA-imidazole buffer (150-mM sucrose, 10-mM EDTA, 50-mM imidazole, $\mathrm{pH}$ 7.3), snap frozen, and stored at $-80^{\circ} \mathrm{C}$.

A blood sample was collected from the caudal vein 
TABLE 1.-Mean (SE in parentheses) fork length (FL, cm), mass $(\mathrm{g})$, condition factor $\left(\mathrm{CF}=100 \times\left[\mathrm{mass}_{\mathrm{FL}}{ }^{3}\right]\right)$, and observed mortalities for control (C) and descaled (D) juvenile Atlantic salmon after transfer to 35\% seawater at 0, 1, 3, or $7 \mathrm{~d}$ after treatment for early, middle, and late series. Data are means for 15 fish (120 fish for all dates). Differences between descaled and control fish within $1 \mathrm{~d}$ are signified by asterisks. Differences between the early, middle, and late series (all fish) are indicated by different letters.

\begin{tabular}{|c|c|c|c|c|c|c|c|c|c|}
\hline \multirow[b]{2}{*}{ Series } & \multirow[b]{2}{*}{ Day } & \multicolumn{2}{|c|}{ FL } & \multicolumn{2}{|c|}{ Mass } & \multicolumn{2}{|c|}{$\mathrm{CF}$} & \multicolumn{2}{|c|}{ Mortalities } \\
\hline & & C & D & C & D & C & D & $\mathrm{C}$ & $\mathrm{D}$ \\
\hline \multirow[t]{5}{*}{ Early } & 0 & $18.6(0.3)$ & $18.2(0.3)$ & $65.4(3.7)$ & $60.4(2.9)$ & $1.01(0.01)$ & $0.99(0.02)$ & 0 & 0 \\
\hline & 1 & $18.7(0.2)$ & $18.8(0.3)$ & $67.8(2.4)$ & $66.8(3.5)$ & $1.03(0.01)$ & $0.99(0.01)$ & 0 & 0 \\
\hline & 3 & $18.6(0.2)$ & $17.8(0.3)$ & $65.3(2.9)$ & $57.2(2.5)$ & $1.01(0.02)$ & $1.01(0.02)$ & 0 & 0 \\
\hline & 7 & $18.2(0.3)$ & $18.6(0.2)$ & $61.1(2.6)$ & $64.1(2.8)$ & $1.00(0.01)$ & $0.99(0.01)$ & 0 & 0 \\
\hline & All & $18.4(0.1) \mathrm{z}$ & & $63.6(1.1) \mathrm{z}$ & & $1.00(0.01) \mathrm{z}$ & & 0 & 0 \\
\hline \multirow[t]{5}{*}{ Middle } & 0 & $19.6(0.3)$ & $19.6(0.3)$ & 75.3 (3.5) & $71.8(3.2)$ & $0.99(0.01)^{*}$ & $0.94(0.01)$ & 0 & 0 \\
\hline & 1 & $19.3(0.2)$ & $19.4(0.3)$ & $67.4(2.2)$ & $70.4(3.4)$ & $0.93(0.01)$ & $0.95(0.01)$ & 0 & 0 \\
\hline & 3 & $19.8(0.3)$ & $19.8(0.2)$ & $75.7(2.8)$ & $74.8(2.2)$ & $0.98(0.03)$ & $0.96(0.01)$ & 0 & 0 \\
\hline & 7 & $20.1(0.2)$ & $19.4(0.3)$ & 76.7 (2.6) & 69.7 (2.6) & $0.94(0.01)$ & $0.95(0.01)$ & 0 & 0 \\
\hline & All & $19.6(0.1) \mathrm{y}$ & & $72.7(1.0) \mathrm{y}$ & & $0.96(0.01)$ у & & 0 & 0 \\
\hline \multirow[t]{5}{*}{ Late } & 0 & $21.4(0.2)$ & $20.6(0.2)$ & $89.1(3.4)$ & 78.7 (3.5) & $0.91(0.01)$ & $0.90(0.01)$ & 0 & 1 \\
\hline & 1 & $21.3(0.4)$ & $20.9(0.2)$ & $92.3(6.5)$ & $83.0(2.8)$ & $0.93(0.01)$ & $0.90(0.01)$ & 0 & 0 \\
\hline & 3 & $20.6(0.1)$ & $20.8(0.3)$ & 78.8 (1.9) & 81.9 (3.5) & $0.89(0.01)$ & $0.91(0.01)$ & 0 & 0 \\
\hline & 7 & $21.3(0.3)$ & $21.0(0.3)$ & $84.6(3.2)$ & $83.8(3.5)$ & $0.87(0.01)$ & $0.90(0.01)$ & 0 & 0 \\
\hline & All & $21.0(0.1) \mathrm{x}$ & & $84.0(1.3) \mathrm{x}$ & & $0.90(0.01) \times$ & & 0 & 1 \\
\hline
\end{tabular}

into a 1-mL ammonium-heparinized syringe. The needle was removed and the blood was expelled into a 1.8-mL centrifuge tube; a sample was then drawn into an ammonium-heparinized hematocrit tube. This tube was kept on ice for less than $10 \mathrm{~min}$ and then centrifuged at $13,500 \times$ gravity $(g)$ for $5 \mathrm{~min}$, and the hematocrit was measured. The remaining tube of blood was spun at $2,000 \times g$ for $5 \mathrm{~min}$; the plasma was removed into a $0.5-\mathrm{mL}$ tube, frozen, and stored at $-80^{\circ} \mathrm{C}$ for subsequent analysis.

Gill $\mathrm{Na}^{+}, \mathrm{K}^{+}$-ATPase assay.-Gill $\mathrm{Na}^{+}, \mathrm{K}^{+}$-ATPase activity was determined using the microplate method described by McCormick (1993). Kinetic analysis of ouabain-inhibitable ATP hydrolysis was measured in triplicate at $25^{\circ} \mathrm{C}$ by monitoring the NADH concentration at $340 \mathrm{~nm}$. Protein concentration of the gill homogenate was determined in triplicate using the bicinchoninic acid (BCA) method (Smith et al. 1985; BCA Protein Kit, Pierce, Rockford, Illinois) using bovine serum albumen as the standard. Activity of gill $\mathrm{Na}^{+}, \mathrm{K}^{+}$-ATPase is expressed as micromoles of inorganic phosphate per milligram of protein per hour $\left(\mu \mathrm{mol} \mathrm{PO}_{4} \cdot \mathrm{mg}\right.$ protein $\left.{ }^{-1} \cdot \mathrm{h}^{-1}\right)$.

Plasma ion and osmolality analysis.-Plasma potassium, sodium, and chloride ion concentrations were measured using an EasyLyte electrolyte analyzer (Medica Corporation, Bedford, Massachusetts) with internal calibration and single-point external standard verification for sodium and chloride (200-mM NaCl). Plasma osmolality was measured using an Advanced Instruments Model 3200 freezing point depression osmometer (Advanced Instruments, Inc., Norwood,
Massachusetts) with 50-, 290-, and 850-milliosmole (mOsm) external standards.

Statistics and calculations.-Data were analyzed using a three-way analysis of variance (ANOVA) with series, day of transfer to seawater, and treatment as independent factors. If series or interactions with other factors were significant, contrasts among means were tested using two-way ANOVAs within each series using day of transfer and treatment as factors. Differences among means were tested, when warranted, with a oneway ANOVA. A Bonferroni $t$-test was used for pairwise comparisons. Where normality tests failed, analyses were performed on ranked data. An a priori significance level of 0.05 was used for all statistical tests.

\section{Results \\ Length, Mass, and Condition Factor}

Although FL and mass increased through the three series, mean FL and mass did not differ between treatments (descaled and control) within each series or among time points (Table 1). Condition factor decreased through successive series (Table 1). Mean condition factor differed between the descaled and control treatments only once among all comparisons by day of transfer for the three series $(0 \mathrm{~d}$ posttreatment in the middle series). Among the control fish sampled through the middle series, mean condition factor at the start $(0 \mathrm{~d}$ posttreatment) was also greater than the mean for fish collected at $1 \mathrm{~d}$ posttreatment.

\section{Gill $\mathrm{Na}^{+}, \mathrm{K}^{+}$-ATPase Activity}

There was no difference in gill $\mathrm{Na}^{+}, \mathrm{K}^{+}$-ATPase activity between treatments (descaled and control) 


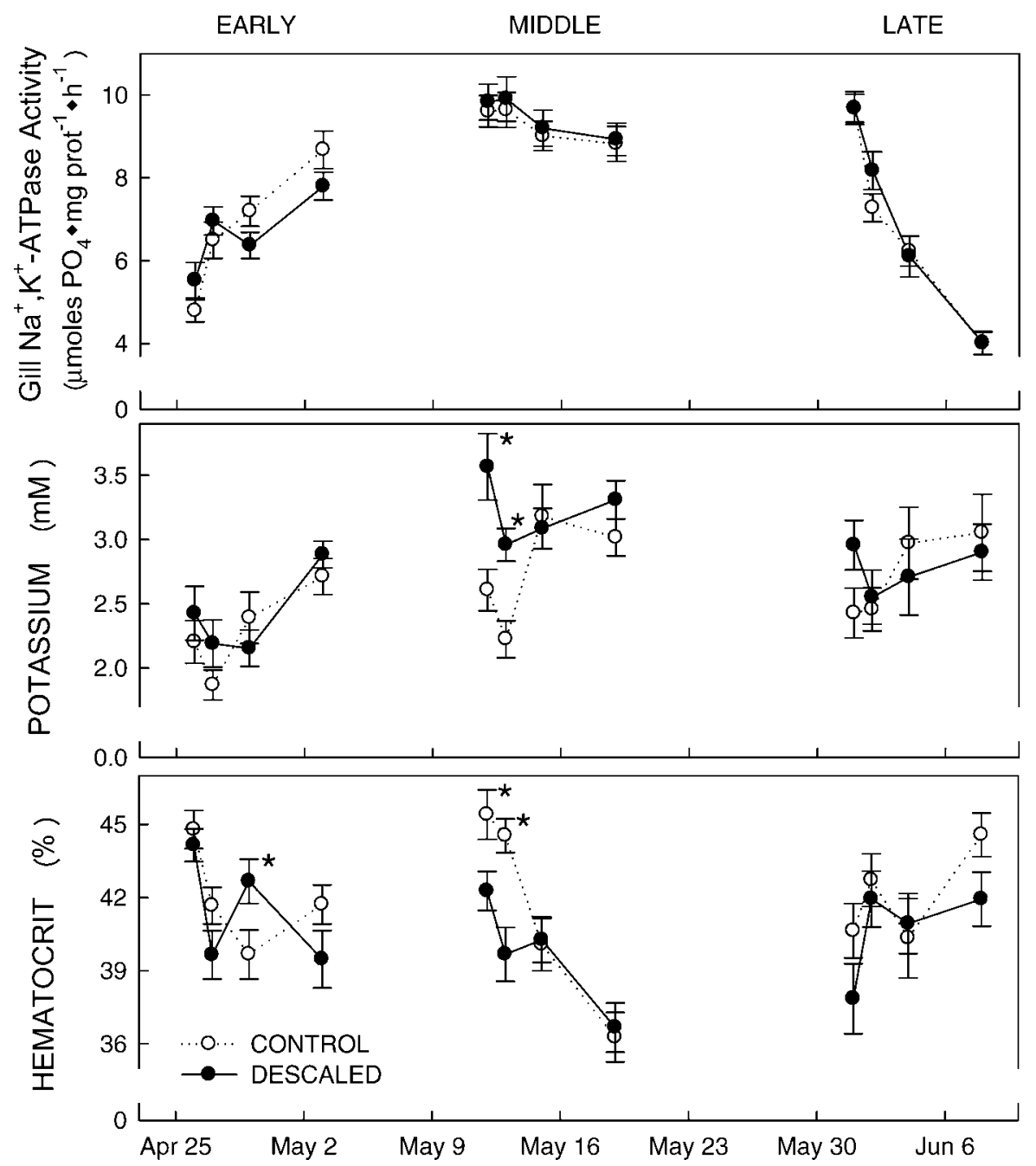

Figure 2.-Mean $( \pm \mathrm{SE})$ gill $\mathrm{Na}^{+}, \mathrm{K}^{+}$-ATPase activity $\left(\mu \mathrm{mol} \mathrm{PO}_{4} \cdot \mathrm{mg}\right.$ protein $\left.{ }^{-1} \cdot \mathrm{h}^{-1}\right)$, plasma potassium $(\mathrm{mM})$, and hematocrit (\% volume) for control and descaled juvenile Atlantic salmon after transfer to 35\%o seawater at $0,1,3$, and $7 \mathrm{~d}$ posttreatment for the early, middle, and late series (defined in Methods). Statistical differences $(P<0.05)$ between descaled and control fish on a given date are indicated by asterisks.

during the three series (Figure 2). During the early series, gill $\mathrm{Na}^{+}, \mathrm{K}^{+}$-ATPase activity increased from 5.2 to $8.2 \mu \mathrm{mol} \mathrm{PO}_{4} \cdot \mathrm{mg}$ protein ${ }^{-1} \cdot \mathrm{h}^{-1}(58 \%)$ over $7 \mathrm{~d}$. Gill $\mathrm{Na}^{+}, \mathrm{K}^{+}$-ATPase activity did not change through the middle series, ranging from 8.8 to $9.8 \mu \mathrm{mol} \mathrm{PO}_{4} \cdot \mathrm{mg}$ protein $^{-1} \cdot \mathrm{h}^{-1}$. Activity declined sharply from 9.7 to $4.0 \mu \mathrm{mol} \mathrm{PO}_{4} \cdot \mathrm{mg}$ protein ${ }^{-1} \cdot \mathrm{h}^{-1}$ during the late series.

\section{Control Fish: Plasma Osmolality, Ions, and Hematocrit}

For control fish, series was a significant factor when comparing plasma osmolality and ion data. In general, osmolality sodium and chloride were lowest in the early series and highest in the late series (Figure 3). Control plasma osmolality changed over each of the samplings, but the changes were slight and patterns differed. During the early series sampling, there was a 24-mOsm decline from 0 to $7 \mathrm{~d}$ posttreatment. During the middle-series sampling, there was no difference in osmolalities at 0 and $7 \mathrm{~d}$, but osmolality at $3 \mathrm{~d}$ was lower. In contrast, during the late-series sampling, there was an increase in osmolality such that by $7 \mathrm{~d}$, the average osmolality of control fish was $45 \mathrm{mOsm}$ higher than that observed at $0 \mathrm{~d}$.

For the control fish, trends in plasma sodium and chloride generally tracked the plasma osmolality trends 


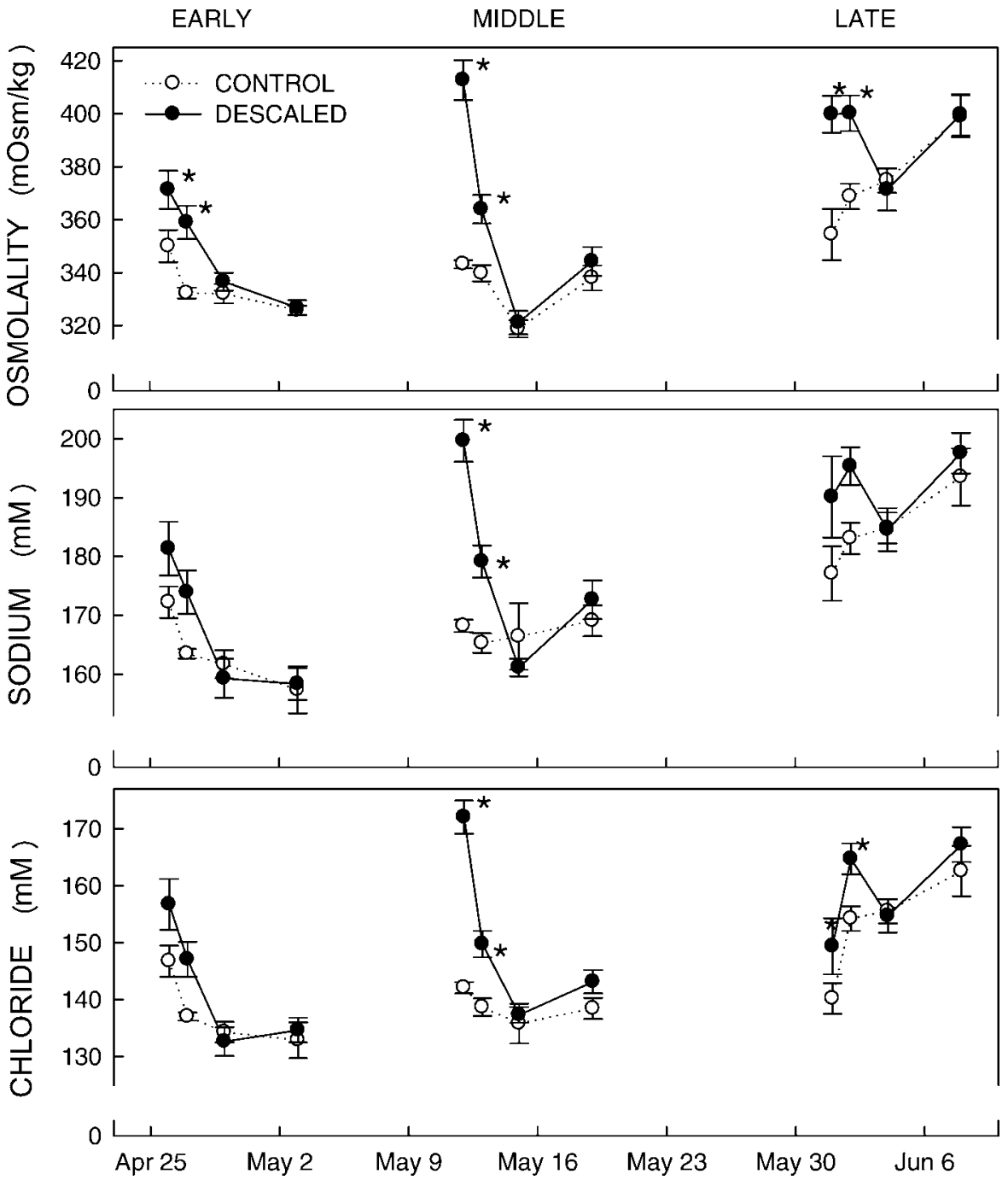

Figure 3.- Mean ( \pm SE) plasma osmolality (milliosmoles $[\mathrm{mOsm}] / \mathrm{kg})$, sodium $(\mathrm{mM})$, and chloride (mM) for control and descaled juvenile Atlantic salmon after transfer to $35 \%$ seawater at $0,1,3$, and $7 \mathrm{~d}$ posttreatment for the early, middle, and late series (defined in Methods). Statistical differences $(P<0.05)$ between descaled and control fish on a given date are indicated by asterisks.

(Figure 3). In the early series, plasma sodium and chloride declined from 0 to $7 \mathrm{~d}$ posttreatment. Middleseries plasma sodium and chloride concentrations did not differ between 0 and $7 \mathrm{~d}$. In sharp contrast to the previous two series (but consistent with plasma osmolality), plasma sodium and chloride increased from 0 to $7 \mathrm{~d}$ in late-series fish. Plasma potassium changes were small but generally increased from 0 to $7 \mathrm{~d}$ in the early and middle series (Figure 2). Plasma potassium did not differ among days of transfer for the late series.

Control fish exhibited a general pattern of decline in hematocrit in the early and middle series (Figure 2). In the early series, hematocrit was lower at $3 \mathrm{~d}$ posttreatment than at $0 \mathrm{~d}$, but hematocrit at $7 \mathrm{~d}$ did not differ from that at $3 \mathrm{~d}$. Declines observed in the middle series were more pronounced (from $45 \%$ at $0 \mathrm{~d}$ to $36 \%$ at $7 \mathrm{~d}$ ). In contrast, the pattern in hematocrit in the late series was one of increase: $41 \%$ at $0 \mathrm{~d}$ and $47 \%$ at $7 \mathrm{~d}$. No control fish died in seawater (Table 1).

Effect of Descaling: Plasma Osmolality, Ions, and Hematocrit

In each of the three series, the descaled fish transferred at $0 \mathrm{~d}$ posttreatment exhibited a marked 
perturbation of plasma osmolality in comparison with control fish (Figure 3). The greatest osmolality increase (70 mOsm) was observed in the middle series, whereas more modest increases were recorded for the early and late series (21 and $46 \mathrm{mOsm}$, respectively). For each of the three series, plasma osmolality of descaled fish was greater than that of control fish at 0 and $1 \mathrm{~d}$ but did not differ from the osmolality of control fish at 3 or $7 \mathrm{~d}$.

A similar pattern was observed in plasma sodium, potassium, and chloride, although pairwise comparisons between descaled and control fish were significant for only the middle and late series (Figures 2, 3). For the early series, treatment had no effect on plasma sodium and potassium but was a significant factor for plasma chloride. For the middle series, plasma sodium, potassium, and chloride of descaled fish were greater than those of control fish at 0 and $1 \mathrm{~d}$ posttreatment but did not differ at 3 or $7 \mathrm{~d}$. The differences were greatest at $0 \mathrm{~d}$. By $1 \mathrm{~d}$ posttreatment, while significantly higher, the differences between descaled and control fish were lessened.

During the late series, plasma chloride of descaled fish was significantly higher than that of control fish at 0 and $1 \mathrm{~d}$ posttreatment but did not differ from control levels at 3 or $7 \mathrm{~d}$. Treatment was a significant factor for plasma sodium but not for potassium. There were no differences between descaled and control fish at any point for plasma sodium.

The hematocrit of descaled fish differed from that of control fish during the early and middle series but not during the late series (Figure 2). In the early series, hematocrit was higher for the descaled fish at $3 \mathrm{~d}$ posttreatment but did not differ on any other day. In the middle series, descaled fish had lower hematocrit levels than control fish at 0 and $1 \mathrm{~d}$ posttreatment. One mortality was observed in the late series; a descaled fish died during the 0 -d transfer to seawater (Table 1).

\section{Discussion}

The descaling experiments spanned the period of early smolting through de-smolting, as evidenced by gill $\mathrm{Na}^{+}, \mathrm{K}^{+}$-ATPase activity, seawater tolerance, and condition factor. Increasing gill $\mathrm{Na}^{+}, \mathrm{K}^{+}$-ATPase activity in the early series provided evidence that the fish were smolting (Figure 2). Gill $\mathrm{Na}^{+}, \mathrm{K}^{+}$-ATPase activity $\left(8.8-9.8 \mu \mathrm{mol} \mathrm{PO}_{4} \cdot \mathrm{mg}\right.$ protein $\left.{ }^{-1} \cdot \mathrm{h}^{-1}\right)$ in the middle series was consistent with reported values at the peak of smolting in Atlantic salmon at the Green Lake National Fish Hatchery (S. McCormick, U.S. Geological Survey [USGS], unpublished data). The rapid decline in gill $\mathrm{Na}^{+}, \mathrm{K}^{+}$-ATPase activity over the 7-d experiment in the late series indicated that these fish were undergoing de-smoltification.

Osmoregulatory ability of control Atlantic salmon paralleled observations for gill $\mathrm{Na}^{+}, \mathrm{K}^{+}$-ATPase activity. In the early and middle series, Atlantic salmon osmoregulated effectively, maintaining low levels of plasma chloride, sodium, and osmolality after seawater challenge (Figure 3). Control fish in the late series exhibited high and increasing levels of plasma osmolality, sodium, and chloride, demonstrating a clear decline in osmoregulatory ability associated with de-smolting. Smolt developmental stage is further evidenced by declining condition factor through the experiments (Table 1).

Regardless of whether the fish were smolting, at the peak of smolting, or de-smolting, descaling resulted in a significant decrease in ability to osmoregulate in seawater for the first $3 \mathrm{~d}$ after injury. Early series smolts experienced a small (but physiologically significant) perturbation in osmolality (21 mOsm), but sodium, potassium, and chloride levels were not affected. The greatest descaling effect was observed at the peak of smolting (Figure 3), when there was a 70mOsm perturbation in plasma osmolality and parallel increases in plasma ions. Descaling in the late sampling had a similarly severe impact, with one mortality observed in the group transferred to seawater at $0 \mathrm{~d}$ posttreatment (Table 1). After $3 \mathrm{~d}$ of recovery in freshwater, descaled fish did not differ from control fish in the ability to perform during a 24-h seawater challenge. The recovery to control levels within this time frame in each series is probably due to epithelial repair.

These results suggest a difference in response, possibly mediated through ontogenic changes in the stress response (Specker 1982; Barton et al. 1985; Carey and McCormick 1998). Although not assessed in this study, the handling and descaling injuries administered were probably accompanied by a stress response. A higher level of osmotic perturbation in the control group transferred to seawater at $0 \mathrm{~d}$ (as observed in the early series; Figure 3) may be due to handling stress (as observed by Gadomski et al. 1994). The recovery of cortisol to normal levels, however, would probably be complete in less than $24 \mathrm{~h}$, and therefore the stress response would have a lesser impact on later data points. Other physiological responses (e.g., plasma glucose) may take longer to return to normal (Carey and McCormick 1998). Additionally, returning to the tank to net fish may likewise have exerted a low amount of stress on both the descaled and control fish. Even so, stress-mediated impacts on osmoregulatory ability through handling and injury are unlikely to be as significant as the descaling injury itself.

Temperature probably did not exert a great influence on the observed differences in performance between 
experimental series. Temperature ranges of the early and middle series differed modestly $\left(7-8^{\circ} \mathrm{C}\right.$ versus $9-$ $\left.12^{\circ} \mathrm{C}\right)$, yet the injured fish exhibited starkly differing physiological responses. A direct influence of temperature however cannot be fully dismissed in this study. Temperature can influence ionic homeostasis due to a respiratory-osmoregulatory compromise (Randall et al. 1972; Redding et al. 1991; Gonzalez and McDonald 1992). However, the far greater effect of temperature in this study is likely to be through the modulation of smolt development (Staurnes et al. 1994).

The fact that the greatest effects of descaling were observed in fish at the peak of smolting and at desmolting is significant. Migrating smolts would therefore be most vulnerable to a high level of osmotic perturbation if injured and directly entering seawater. Descaling injuries are frequent in Atlantic salmon smolts during and after the peak of migration in the Penobscot River (USASAC 2006), probably due to the increased deciduous nature of scales during smolting (Hoar 1988). The injury administered in this study is modest relative to that encountered in Atlantic salmon smolts in the Penobscot River (Shepard 1993; NOAA Fisheries, unpublished data) and Chinook salmon Oncorhynchus tshawytscha in the Columbia River (Gessel et al. 1991), where descaling injuries of less than $20 \%$ are considered "low." Because of this and the fact that the descaling injury in this study was administered without bruising or other potential impacts, the observed perturbations in this study should be considered modest.

Even so, such perturbations can increase smolts' vulnerability to predation (Handeland et al. 1996). The estuary is indeed an area of high smolt mortality; in the Penobscot River, 10-30\% of acoustic-tagged Atlantic salmon smolts are lost in this region (Holbrook 2007). Blackwell and Krohn (1997) suggested that the selection by double-crested cormorants Phalacrocorax auritus for foraging areas near dams reflects a higher availability of prey, possibly due to delay and injury.

This study demonstrated a notable impact of modest descaling to smolts placed in seawater. In contrast, other work suggests that descaling injuries of salmon result in a less-severe impact on ionic homeostasis while in freshwater (e.g., Chinook salmon; Gadomski et al. 1994). Descaling resulted in a short-term risk of increased predation, with no evidence for longer-term adverse effects on performance and survival in freshwater. If recovery from a descaling injury is less physiologically severe in freshwater, injured smolts may remain in freshwater until their injury has healed. Such a behavior, however, would expose these fish to riverine predators over a greater period. Remaining in freshwater may also hasten de-smolting (Muir et al.
1994; McCormick et al. 1999; Zydlewski et al. 2005), further compromising successful migration.

\section{Acknowledgments}

The authors thank the biologists at the Green Lake National Fish Hatchery, especially Fred Trasko, for invaluable assistance. We thank Randy Spencer, Casey Jackson, Christopher Holbrook, Aline Barbin, and Orion Zydlewski for their assistance in sampling and analysis. Lauren Holbrook provided key laboratory expertise. Additional thanks go to Steve Coghlan and Joan Trial for their review of the manuscript. This research was funded by the University of Maine, Maine Department of Inland Fisheries and Wildlife, and USGS Maine Cooperative Fish and Wildlife Research Unit. Reference to trade names and commercial products does not imply endorsement or recommendation by the U.S. Government. We remember the contributions and encouragement of Ed Hastings from NOAA Fisheries. We also remember the conversations with Clem Fay, representing the Penobscot Nation, whose interest in the subject stimulated this work. Both Ed and Clem are missed.

\section{References}

Barton, B. A., C. B. Schreck, R. D. Ewing, A. R. Hemmingsen, and R. Patino. 1985. Changes in plasma cortisol during stress and smoltification in coho salmon, Oncorhynchus kisutch. General and Comparative Endocrinology 59:468-471.

Blackwell, B. F., and W. B. Krohn. 1997. Spring foraging distribution and habitat selection by double-crested cormorants on the Penobscot River, Maine, USA. Colonial Waterbirds 20:66-76.

Bouck, G. R., and S. D. Smith. 1979. Mortality of experimentally descaled smolts of coho salmon (Oncorhynchus kisutch) in fresh and salt water. Transactions of the American Fisheries Society 108:67-69.

Carey, J. B., and S. D. McCormick. 1998. Atlantic salmon smolts are more responsive to an acute handling and confinement stress than parr. Aquaculture 68:237-253.

FERC (Federal Energy Regulatory Commission). 1989. Report on downstream passage of Atlantic salmon smolts and kelts at Weldon Dam, Mattaceunk Project. FERC, Report 2520, Washington, D.C.

Gadomski, D. M., M. G. Mesa, and T. M. Olson. 1994. Vulnerability to predation and physiological stress responses of experimentally descaled juvenile Chinook salmon, Oncorhynchus tshawytscha. Environmental Biology of Fishes (Netherlands) 39:191-199.

Gessel, M. H., J. G. Williams, D. A. Brege, R. Krcma, and D. R. Chambers. 1991. Juvenile salmonid guidance at the Bonneville Dam Second Powerhouse, Columbia River, 1983-1989. North American Journal of Fisheries Management 11:400-412.

Gonzalez, R. J., and D. G. McDonald. 1992. The relationship between oxygen consumption and ion loss in freshwater fish. Journal of Experimental Biology 163:317-332. 
Handeland, S. O., T. Jaervi, A. Fernoe, and S. O. Stefansson. 1996. Osmotic stress, antipredator behaviour, and mortality of Atlantic salmon (Salmo salar) smolts. Canadian Journal of Fisheries and Aquatic Sciences 53:2673-2680.

Handeland, S. O., E. Wilkinsson, and S. O. Stefansson. 2001. Smolting and de-smolting at different temperatures in two strains of Atlantic salmon (Salmo salar L.). Institutt for Fiskeri-og Marinbiologi Rapport Bergen 10:1-20.

Hoar, W. S. 1988. The physiology of smolting salmonids. Pages 323-343 in W. S. Hoar and D. J. Randall, editors. Fish physiology, volume 11, part B. Academic Press, New York.

Holbrook, C. 2007. Behavior and survival of migrating Atlantic salmon (Salmo salar) in the Penobscot River and estuary, Maine: acoustic telemetry studies with smolts and adults. Master's thesis. University of Maine, Orono.

Holeton, G. F., M. G. Pawson, and G. Shelton. 1982. Gill ventilation, gas exchange, and survival in the Atlantic mackerel (Scomber scombrus L.). Canadian Journal of Zoology 60:1141-1147.

IUBMB (International Union of Biochemistry and Molecular Biology). 1992. Enzyme nomenclature 1992. Academic Press, San Diego, California.

Kuperman, B. I., V. E. Matey, and S. H. Hurlbert. 2001. Parasites of fish from the Salton Sea, California, USA. Hydrobiologia 466:195-208.

McCormick, S. D. 1993. Methods for non-lethal gill biopsy and measurement of $\mathrm{Na}^{+}, \mathrm{K}^{+}$-ATPase activity. Canadian Journal of Fisheries and Aquatic Sciences 50:656-658.

McCormick, S. D., R. A. Cunjak, B. Dempson, M. O'Dea, and J. B. Carey. 1999. Temperature-related loss of smolt characteristics in Atlantic salmon (Salmo salar) in the wild. Canadian Journal of Fisheries and Aquatic Sciences 56:1649-1658.

McCormick, S. D., L. P. Hansen, T. P. Quinn, and R. L. Saunders. 1998. Movement, migration, and smolting of Atlantic salmon (Salmo salar). Canadian Journal of Fisheries and Aquatic Sciences 55:77-92.

McCormick, S. D., and R. L. Saunders. 1987. Preparatory physiological adaptations for marine life in salmonids: osmoregulation, growth, and metabolism. Pages 211-229 in M. J. Dadswell, R. J. Klauda, C. M. Moffitt, R. L. Saunders, R. A. Rulifson, and J. E. Cooper, editors. Common strategies of anadromous and catadromous fishes. American Fisheries Society, Symposium 1, Bethesda, Maryland.

Muir, W. D., W. S. Zaugg, A. E. Giorgi, and S. McCutcheon. 1994. Accelerating smolt development and downstream movement in yearling Chinook salmon with advanced photoperiod and increased temperature. Aquaculture 123:387-399.

Randall, D. J., D. Baumgarten, and M. Malyusz. 1972. The relationship between gas and ion transfer across gills in fishes. Comparative Biochemistry and Physiology 41A:629-637.

Redding, J. M., R. Patino, and C. B. Schreck. 1991. Cortisol effects on plasma electrolytes and thyroid hormones during smoltification in coho salmon Oncorhynchus kisutch. General and Comparative Endocrinology 81:373-382.

Richman, N. H. III, S. Tai de Diaz, R. S. Nishioka, P. Prunet, and H. A. Bern. 1987. Osmoregulatory and endocrine relationships with chloride cell morphology and density during smoltification in coho salmon (Oncorhynchus kisutch). Aquaculture 60:265-285.

Shepard, S. L. 1993. Survival and timing of Atlantic salmon smolts passing the West Enfield hydroelectric project. Report to the U.S. Federal Energy Regulatory Commission, Bangor Hydro-Electric Company, Bangor, Maine.

Smith, P. K., R. I. Krohn, G. T. Hermanson, A. K. Mallia, F. H. Gartner, M. D. Provenzano, E. K. Fujimoto, N. M. Goeke, B. J. Olson, and D. C. Klenk. 1985. Measurements of protein using bicinchoninic acid. Analytical Biochemistry 150:76-85.

Specker, J. L. 1982. Interrenal function and smoltification. Aquaculture 28:59-66.

Staurnes, M., T. Sigholt, and O. A. Gulseth. 1994. Effects of seasonal changes in water temperature on the parr-smolt transformation of Atlantic salmon and anadromous arctic char. Transactions of the American Fisheries Society 123:408-415.

USASAC (U.S. Atlantic Salmon Assessment Committee). 2006. Annual report of the U.S. Atlantic Salmon Assessment Committee 2006/18. USASAC, Gloucester, Massachusetts.

Zydlewski, G. B., A. Haro, and S. D. McCormick. 2005. Evidence for cumulative temperature as an initiating and terminating factor in downstream migratory behavior of Atlantic salmon (Salmo salar) smolts. Canadian Journal of Fisheries and Aquatic Sciences 62:68-78. 